\title{
An extraction-free method by which a single slot blot can be used to quantify intracellular DNA damage (crosslinks or strand breaks) and changes in DNA damage response proteins or replication
}

\author{
Mary M. McHugh and Terry A. Beerman \\ Pharmacology and Therapeutics, Roswell Park Cancer Institute, Buffalo, \\ NY, USA
}

BioTechniques 46:127-129 (February 2009) doi 10.2144/000113046

Keywords: immunodetection; bromodeoxyuridine; $\gamma$-H2AX, DNA damage; Hybond N+; slot blot; C-1027; bizelesin

We report an extraction-free assay in which the same slot blot membrane can be used to assess total genomic DNA damage (i.e., crosslinks or strand breaks) and DNA replication (i.e., bromodeoxyuridine incorporation) or protein levels (i.e., $\gamma$-H2AX). ${ }^{14} \mathrm{C}$-thymidine radiolabeling of HCT116 cells loaded directly on a Hybond $\mathrm{N}+$ membrane slot blot enables the quantitation of DNA interstrand crosslinks and DNA breaks, while bromodeoxyuridine incorporation or levels of $\gamma$-H2AX can be assessed by incubating blots with primary monoclonal antibodies followed by detection with horseradish peroxidase (HRP) secondary antibodies. Uniform Ponceau staining of all samples on the membrane indicates that protein binding to the membrane is independent of DNA damage or elution. The use of a single membrane to assay levels of DNA damage and concomitant changes in damage response proteins or replication allows the direct quantitation of diverse parameters under identical conditions.

Insults to the DNA of living cells can induce diverse lesions, the more lethal being DNA strand breaks and DNA interstrand crosslinks (1). These lesions have been characterized by methods such as alkaline sucrose gradients or alkaline filter elution (2) and, more recently, the single cell gel electrophoresis (Comet) assay (3). DNA damage can initiate a host of cellular responses, among them changes in replication [i.e., bromodeoxyuridine (BrdU) incorporation into DNA (4)], and in damage-signaling proteins such as the double-strand break indicator $\gamma$ - $\mathrm{H} 2 \mathrm{AX}$ (5). These responses can be monitored using flow cytometry or Western blotting, respectively, which are both time-consuming and/or expensive procedures.

Previously, Norwood et al. (6) described a method for measuring telomere length by loading intact cells on slot blots. We adapted this procedure so that a single slot blot can be used to assess not only total genomic DNA damage, but also levels of either BrdU incorporation or $\gamma-\mathrm{H} 2 \mathrm{AX}$. HCT 116 cells were grown for $24 \mathrm{~h}$ in 0.06 $\mathrm{uCi} / \mathrm{mL}{ }^{14} \mathrm{C}$-thymidine (Moravek, Brea, CA, USA), followed by treatments to induce DNA damage. When BrdU incorporation was measured, $100 \mu \mathrm{M}$ BrdU (Sigma Aldrich, St. Louis, MO, USA) was added to cells $0.5 \mathrm{~h}$ prior to harvest. Treated cells were removed from plates with trypsin, washed once with phosphate buffered saline (PBS), and adjusted to $1 \times 10^{5}$ cells per $\mathrm{mL}$ in PBS. Slot blots were prepared similarly to the method of Norwood et al., except that Hybond N+ (GE Healthcare Bio-Sciences Corp., Piscataway, NJ, USA) was used instead of Zeta probe. Slots were drained under vacuum at a rate of $0.5 \mathrm{~mL} /$ min. Briefly, slots were washed with $200 \mu \mathrm{L}$ of neutralization solution $(1.5 \mathrm{M} \mathrm{NaCl}, 0.5$ $\mathrm{M}$ Tris, $\mathrm{pH} 7.5)$, and $200 \mu \mathrm{L}$ of cells $(2 \times$ $\left.10^{4}\right)$ were applied to each of three slots per sample and drained. Two hundred microliters of denaturing lysis solution $(1.5 \mathrm{M}$ $\mathrm{NaCl}, 0.5 \mathrm{~N} \mathrm{NaOH}$ ) was applied per slot. After $7 \mathrm{~min}$ of lysis, the slots were drained, and $200 \mu \mathrm{L}$ of neutralization solution were added for an additional $7 \mathrm{~min}$. These slots were used to calculate ${ }^{14} \mathrm{C}$-DNA bound to the membrane. During the second 7-min incubation, $200 \mu \mathrm{L}$ per sample were loaded on each of three additional slots prewetted with neutralization solution. Denaturing lysis solution was not added to these slots which represent total ${ }^{14} \mathrm{C}-\mathrm{DNA}$. All wells were drained, and DNA was crosslinked to the wet membrane with a UV DNA crosslinker (Stratagene Corp, La Jolla, CA, USA). The wet blots were blocked for $1 \mathrm{~h}$ with $5 \%$ milk in Trisbuffered saline, $0.05 \%$ Tween 20, pH 7.5 (TBS-T) and incubated overnight at $4^{\circ} \mathrm{C}$ with primary antibodies to either BrdU $(1 \mu \mathrm{g} / \mathrm{mL}$; DAKO, Carpinteria, CA, USA) or $\gamma$-H2AX $(2 \mu \mathrm{g} / \mathrm{mL}$; Upstate, Lake Placid, NY, USA), diluted in blocking solution. Blots were washed in TBS-T, then incubated for $1 \mathrm{~h}$ in secondary horseradish peroxidase (HRP)-labeled goat anti-mouse antibody (Sigma Aldrich) diluted 1:20,000 in TBS-T. Chemiluminescence was detected on film using Western Chemiluminescent Reagent Plus (PerkinElmer, Waltham, MA, USA). Since the chemiluminescent signal was more than 10 times greater when cells were lysed in denaturing solution rather than neutralization solution (data not shown), denatured samples were used for quantitating immunoblots. $\gamma$ - $\mathrm{H} 2 \mathrm{AX}$ was expressed as a fraction of the control intensity; that is, average sample intensity was divided by average control intensity:

$\gamma-\mathrm{H} 2 \mathrm{AX}($ Fraction of control $)=\frac{\gamma-\mathrm{H} 2 \mathrm{AX}_{\text {sample }}}{\gamma-\mathrm{H} 2 \mathrm{AX} \text { coutrol }}$

[Eq. 1] 
A

\section{C-1027(nM)}

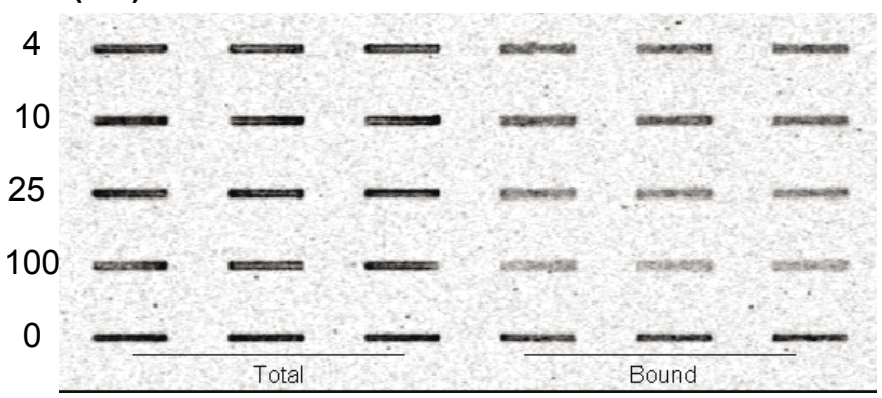

B

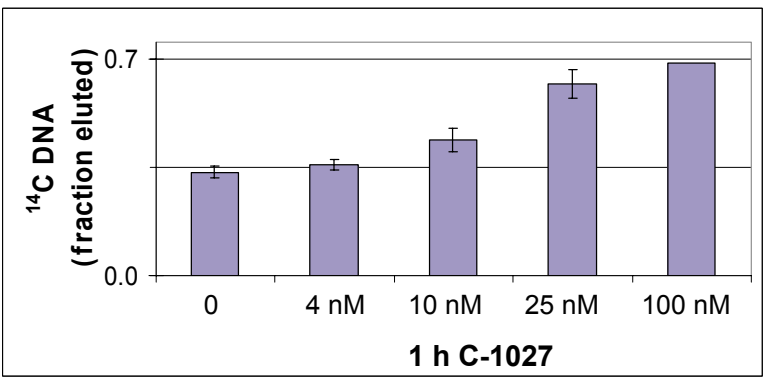

C

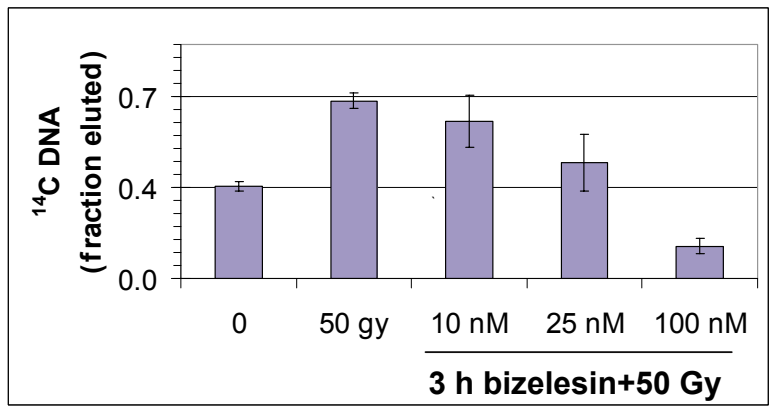

Figure 1. DNA strand breaks and DNA crosslinks in HCT116 cells. (A and B) Strand breaks. Cells were treated for $1 \mathrm{~h}$ with 0-100 nM C-1027. (A) Phosphorimage of a representative slot blot showing a reduction in ${ }^{14} \mathrm{C}$ bound to the membrane with increasing $\mathrm{C}-1027$ (i.e., increasing DNA strand scission). (B) Graphic representation of increased elution of ${ }^{14} \mathrm{C}$ DNA from the membrane caused by $4-100 \mathrm{nM} \mathrm{C}-1027$. (C) Crosslink detection. Cells were treated for $3 \mathrm{~h}$ with 0-100 nM bizelesin followed by 50 Gy IR to induce strand breaks. Bizelesin crosslink inhibition of IR-induced ${ }^{14} \mathrm{C}$-DNA elution is concentration dependent. Data from three separate experiments are plotted in (B) and (C), and are expressed \pm SD.

A

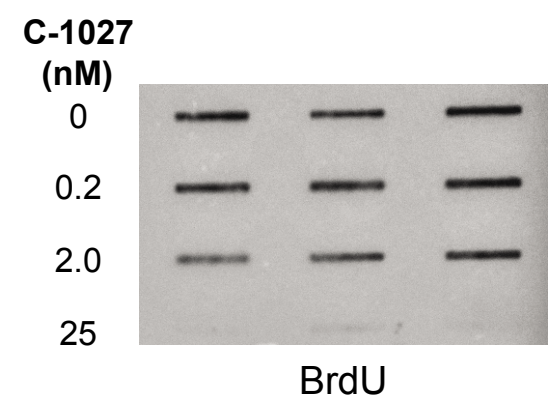

B

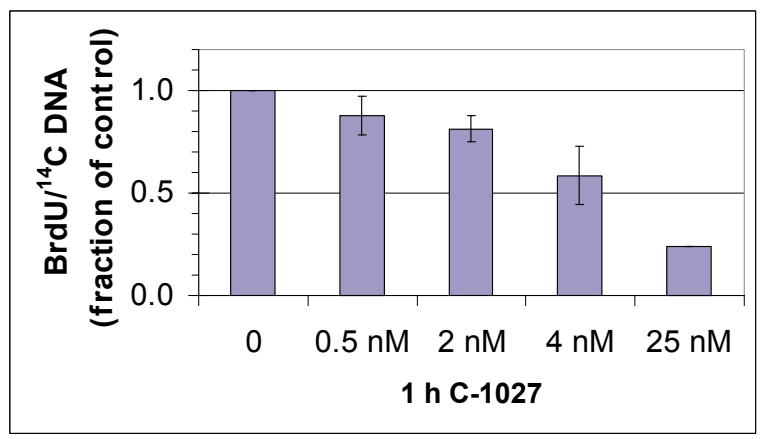

C

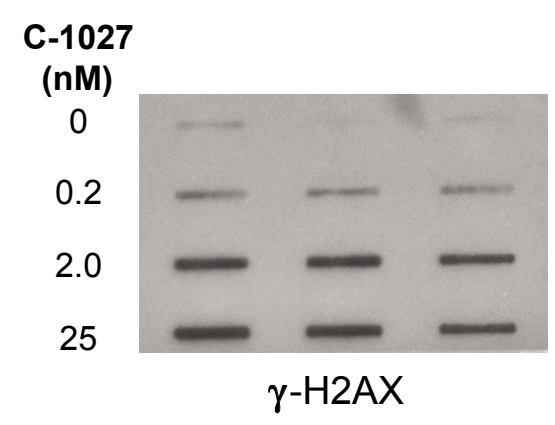

D

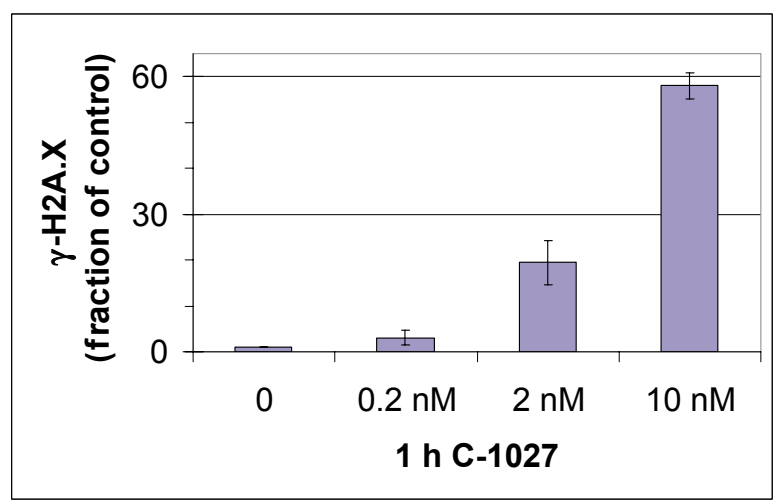

Figure 2. Immunoblots of cells treated with C-1027. (A and B) BrdU incorporation. Cells were treated with $\mathrm{C}-1027$ for $30 \mathrm{~min}$ prior to $100 \mu \mathrm{M}$ BrdU addition, then incubated for an additional $30 \mathrm{~min}$. (A) Representative slot blot showing decreased BrdU incorporation with increasing C-1027. (B) Graphic representation of inhibition of BrdU incorporation by 0.5-25 nM C-1027. (C and D) $\gamma$-H2AX determination. Cells were treated with C-1027 for $1 \mathrm{~h}$. (C) Representative slot blot showing an increase in $\gamma-\mathrm{H} 2 \mathrm{AX}$ with increasing C-1027. (D) Graphic representation showing $\gamma$-H2AX progressively increasing with $0.2-10 \mathrm{nM} \mathrm{C}$-1027. Data from three separate experiments are plotted in (B) and (D), and are expressed \pm SD. 
For ${ }^{14} \mathrm{C}$ detection, the blots were dried and exposed to a Molecular Dynamics phosphorimager screen (GE Healthcare Bio-Sciences Corp.) for $2 \mathrm{~h}$. The ${ }^{14} \mathrm{C}$-DNA bound to the three slots was averaged and compared with the average total ${ }^{14} \mathrm{C}$ to determine the fraction of ${ }^{14} \mathrm{C}$-DNA eluted. The fraction of ${ }^{14} \mathrm{C}$-DNA eluted was calculated as follows:

Fraction eluted $=\frac{\left({ }^{14} \mathrm{CB}_{\text {control }}\right)}{{ }^{14} \mathrm{C} \mathrm{T}}-\frac{\left({ }^{14} \mathrm{C} \mathrm{B}_{\text {sample }}\right)}{{ }^{14} \mathrm{C} \mathrm{T}}$,

[Eq. 2]

where $\mathrm{B}$ is the average ${ }^{14} \mathrm{C}$ bound and $\mathrm{T}$ is the average ${ }^{14} \mathrm{C}$ total. As the $\mathrm{BrdU}$ signal will vary with the absolute amount of DNA on the membrane, as well as with damage-induced effects on replication, BrdU incorporation was expressed relative to the amount of ${ }^{14} \mathrm{C}-\mathrm{DNA}$ bound per slot. Thus, the average bound $\mathrm{BrdU}$ intensity per pixel ${ }^{14} \mathrm{C}$, divided by the average bound control BrdU intensity per pixel ${ }^{14} \mathrm{C}$, was calculated as:

$\frac{\mathrm{BrdU}}{{ }^{14} \mathrm{C}}$ (Fraction of control $)=\frac{\left(\frac{\mathrm{BrdU}}{{ }^{14} \mathrm{C}_{\text {sample }}}\right)}{\left(\frac{\mathrm{BrdU}}{{ }^{14} \mathrm{C}_{\text {control }}}\right)}$

[Eq. 3]

Detection of ${ }^{14} \mathrm{C}$ DNA was linear with $1 \times 10^{4}$ to $5 \times 10^{4}$ cells per well, while optimal chemiluminescence was observed with $2 \times 10^{4}$ cells (data not shown).

Both strand breaks and DNA crosslinks can be detected using this method; this is shown in Figure 1. Figure 1A is a phosphorimage of the ${ }^{14} \mathrm{C}$ profile after cells treated with increasing concentrations of the DNA double-strand scission enediyne C-1027 (7) were loaded on a slot blot and the fraction of ${ }^{14} \mathrm{C}$-DNA eluted was determined. Figure $1 \mathrm{~B}$ shows that the fraction of ${ }^{14} \mathrm{C}-\mathrm{DNA}$ eluted increased with increasing C-1027 (i.e., increasing strand breaks). The presence of crosslinks should decrease elution of DNA from the filter. Figure $1 \mathrm{C}$ shows reduced ${ }^{14} \mathrm{C}-\mathrm{DNA}$ elution when cells were incubated $3 \mathrm{~h}$ with $10-100 \mathrm{nM}$ of the DNA interstrand crosslinker bizelesin (8) prior to $50 \mathrm{~Gy}$ irradiation (IR) to induce strand breaks, compared with IR alone. Thus, bizelesin crosslinking blocked IR-induced DNA elution from the filter.

While damage to DNA limited its binding to the membrane, uniform Ponceau staining of all samples on the slot blot (data not shown) indicated that total protein binding to the membrane was independent of DNA damage or elution. Figure 2 shows that either replication or levels of $\gamma$-H2AX can be assayed on the same blot used to detect DNA damage. Densitometric scans of representative films of BrdU or $\gamma-\mathrm{H} 2 \mathrm{AX}$ detection in cells treated with $\mathrm{C}-1027$ are shown in Figures $2 \mathrm{~A}$ or $2 \mathrm{C}$, respectively. Figure $2 \mathrm{~B}$ shows that $\mathrm{BrdU}$ incorporation decreased progressively after a $1 \mathrm{~h}$ treatment with 0.5-25 nM C-1027, a known replication inhibitor (9). This decrease correlates with an increase in $\gamma$-H2AX (doublestrand breaks) after a $1 \mathrm{~h}$ treatment with 0.2-10 nM C-1027 [see Figure 2, $\mathrm{C}$ and $\mathrm{D}$, in agreement with our earlier studies (10)]. The positively charged nylon membrane, Hybond $\mathrm{N}+$ should bind both double and single-strand DNA over a wide size range. That the slot blot can discriminate between damaged and undamaged DNA may reflect earlier reports that membranes may not bind small DNA fragments efficiently $(11,12)$. It also is possible that draining DNA through the slots under vacuum may not allow sufficient time for smaller DNA fragments to bind to the membrane. The slot blot method is not a replacement for more rigorous measures of DNA damage and cellular responses, but is useful as an extraction-free first step in screening agents for effects on these parameters.

\section{Acknowledgements}

This work was supported in part by National Cancer Institute research grant

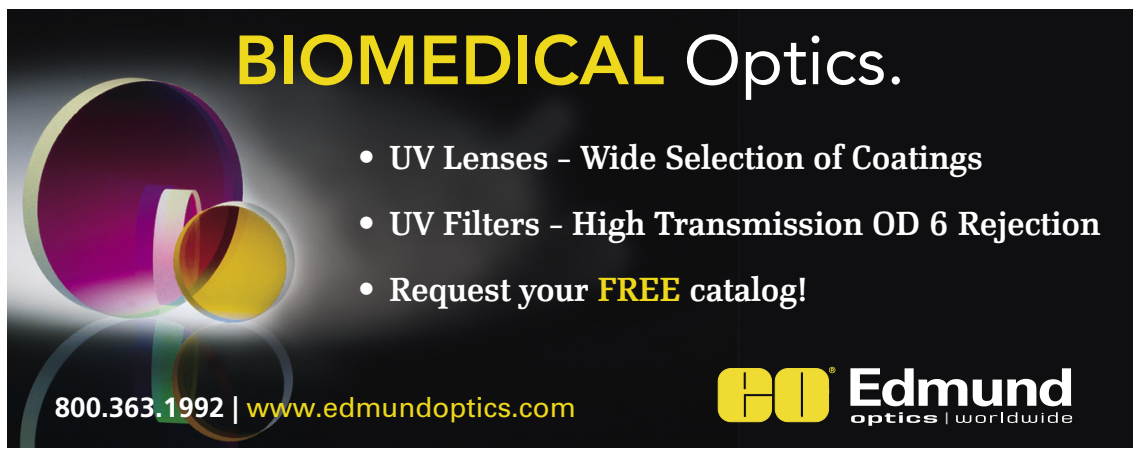

CA106312 (T.B.) and support grant CA16056. This paper is subject to the NIH Public Access Policy.

The authors declare no competing interests.

\section{References}

1. Frankenberg-Schwager, M. 1990. Induction, repair and biological relevance of radiationinduced DNA lesions in eukaryotic cells. Radiat. Environ. Biophys. 29:273-292.

2. Ahnstrom, G. 1988. Techniques to measure DNA single-strand breaks in cells: a review. Int. J. Radiat. Biol. 54:695-707.

3. Collins, A.R. 2004. The comet assay for DNA damage and repair: principles, applications, and limitations. Mol. Biotechnol. 26:249-261.

4. Rothkamm, K., I. Kruger, L.H. Thompson, and M.Lobrich. 2003. Pathways of DNAdoublestrand break repair during the mammalian cell cycle. Mol. Cell. Biol. 23:5706-5715.

5. Tanaka, T., X. Huang, H.D. Halicka, H. Zhao, F. Traganos, A.P. Albino, W. Dai, and Z. Darzynkiewicz. 2007. Cytometry of ATM activation and histone $\mathrm{H} 2 \mathrm{AX}$ phosphorylation to estimate extent of DNA damage induced by exogenous agents. Cytometry A 71:648-661.

6. Norwood, D. and D.S. Dimitrov. 1998 Sensitive method for measuring telomere lengths by quantifying telomeric DNA content of whole cells. Biotechniques 25:1040-1045.

7. Sugiura, Y. and T. Matsumoto. 1993. Some characteristics of DNA strand scission by macromolecular antitumor antibiotic C-1027 containing a novel enediyne chromophore. Biochemistry 32:5548-5553.

8. Skladanowski, A., M. Koba, and J. Konopa. 2001. Does the antitumor cyclopropylpyrroloindole antibiotic CC-1065 cross-link DNA in tumor cells? Biochem. Pharmacol. 61:67-72.

9. McHugh, M.M., T.A. Beerman, and W.C. Burhans. 1997. DNA-damaging enediyne C-1027 inhibits initiation of intracellular SV40 DNA replication in trans. Biochemistry 36:1003-1009.

10. Kennedy, D.R., L.S. Gawron, J. Ju, W. Liu, B. Shen, and T.A. Beerman. 2007. Single chemical modifications of the C-1027 enediyne core, a radiomimetic antitumor drug, affect both drug potency and the role of ataxia-telangiectasia mutated in cellular responses to DNA double-strand breaks. Cancer Res. 67:773-781.

11. Szabo, I., A. Lepple-Wienhues, K.N. Kaba, M. Zoratti, E. Gulbins, and F. Lang. 1998. Tyrosine kinase-dependent activation of a chloride channel in CD95-induced apoptosis in T lymphocytes. Proc. Natl. Acad. Sci. USA 95:6169-6174.

12. Alwine, J.C., D.J. Kemp, and G.R. Stark. 1977. Method for detection of specific RNAs in agarose gels by transfer to diazobenzyloxymethyl-paper and hybridization with DNA probes. Proc. Natl. Acad. Sci. USA 74:53505354 .

Received 27 August 2008; accepted 7 November 2008.

Address correspondence to Mary M. McHugh, Pharmacology and Therapeutics, Roswell Park Cancer Institute, Buffalo, NY, USA, 14263. email: mary.mchugh@roswellpark.org 